\title{
Structures of masonry walls in buildings of permanent ruin - causes of damage and methods of repairs
}

\author{
Bartosz Szostak \\ Department of Conservation of Built Heritage, Faculty of Civil Engineering and Architecture, \\ Lublin University of Technology,e-mail: b.szostak@pollub.pl
}

\begin{abstract}
Currently there is a lot of castles classified as objects of the permanent ruin. In according to conservation doctrine, it is needed to protect this objects and prevent further degradation. Usually one of the most destructed element in this type of object is masonry wall. In this article has been described selected types of the masonry walls of the permanent ruin, causes of their damages and repairs methods.
\end{abstract}

Keywords: ruined castle, masonry walls, repairs, permanent ruin.

\section{Introduction}

Currently in Poland there are more than a hundred castles classified as objects of the permanent ruin. These facilities are very specific both in the conservation and operational approach. The conservation doctrine for these objects presupposes leaving them in a state of ruin while preventing further degradation. It also assumes minimal interference in the historical aspect and the preservation of the form of these objects. Taking into account the operation of such object, it is an extremely difficult challenge for both managers and people dealing with the technical aspects of maintaining the ruin. Designers as well as contractors of construction works are obliged to maintain extreme caution during works (some works may be irreversible and significantly affect the object and reception of the monument itself).

In order to properly design and perform repairs in such facilities, at the very beginning their history, stratigraphy, structure, recommendations, and conservation guidelines need to be known. In the case of an object failure or damage, the cause of the existing condition should also be found in order to remove it. Carrying out works without prior removal of causes may be unfounded and ineffective.

In the paper, the author focused on the elements of the masonry walls, which can be found in buildings of the permanent ruin in Poland. In addition, literature analysis, numerous expert opinions as well as construction and contracting projects were performed to systematize the causes of damage and repair solutions.

\section{Masonry walls in the objects of the permanent ruin}

To analyze the walls it is necessary to know their structure and construction. For different types of walls, a different nature of their destruction occurs and a different method of repair may be needed. Without a detailed diagnosis, it may not be possible to perform the correct project.

As is well known, the bricklaying accompanies the activities of builders almost from the very beginning of the buildings erection. Even in ancient times, structures from properly 
arranged stone blocks were erected. Over the next thousand years humanity gained new experiences in this field. At first, the knowledge of the building construction was passed down from generation to generation and had more of a craft character than engineering. In ancient times, erected constructions were the result of experience and practical knowledge of builders. The same applies to the masonry walls of buildings that are now in a state of the permanent ruin.

\subsection{Selected types of the masonry walls of the permanent ruin}

There were at least several ways to build masonry facilities. It depended on the builders and the availability of raw materials near the construction site. The most popular and, at the same time, the oldest walls are the masonry walls made of broken stone and stone blows joined using a lime mortar. In the construction of these walls, a material from local quarries was usually used. The parameters of these materials can be very diverse. There were many techniques for building masonry structures. However, the most frequent seen are walls made of stone blows and broken rocks. Sometimes layers were created in these walls with smaller, easier to process pieces of rock. In the case of walls of very large thickness, the walls called the "opus emplectum" were used. It was nothing more than making the external and internal face from the hewn block of stone, and then filling the space between the crumbled stone and the mortar. Later the brick was used as the masonry material.

a)

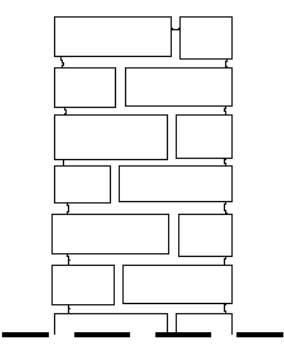

d)

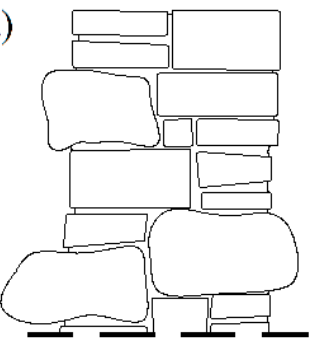

b)

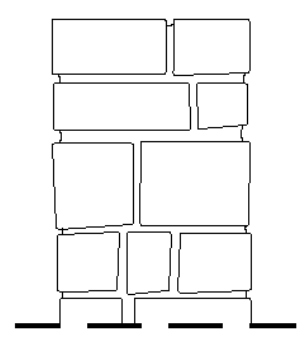

c)

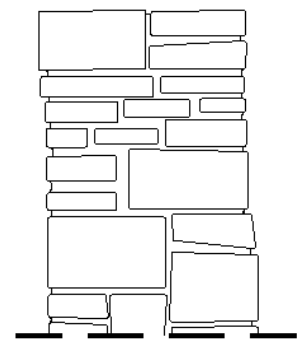

e)

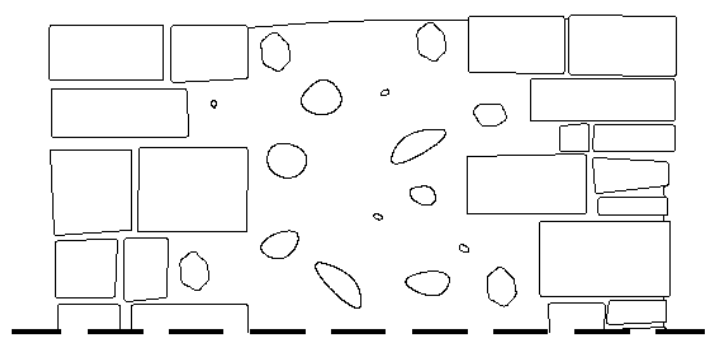

Fig. 1. Selected types of the masonry walls in the ruins of castles - a) wall made of ceramic bricks, b) wall made of stone blows, c) wall made of stone blows with leveling layers, c) wall made of broken stones with boulders, d) the „opus emplectum” wall [1]

It is often impossible to make computational analyzes of such walls. This is due to their irregularity, the inability to determine their internal structure and the exact physical parameters of the materials used. All kinds of works carried out are the result of experience of designers and builders. Only it is possible to perform approximate strength analyzes. The complete mapping of the construction behavior with such specific structure is very complicated and can give quite different results, even using modern computer methods. 


\section{Damage to the masonry wall's structure}

The walls are constructed from small-sized elements connected with a binder. Like every element of the structure, they are damaged due to the excessive stress. Characteristic for the masonry structures is no susceptibility to deformation, unlike other constructions. All kinds of displacements in the structure result in the appearance of cracks and scratches. Not all wall's damages endanger the safety of its use, however, all defects are a sign of irregularities in the performance of wall elements.

To start the correct repair work, firstly, diagnostics should be performed. The diagnostics itself should start with the analysis of the archival documentation and the conditions of the construction operation. Information about earlier reinforcements, repairs, and works carried out related not only to the damaged element but also to the whole building can be crucial in the search for the causes of damage. It should be remembered that removing the consequences of a failure without identifying and removing its causes may be the pointless and short-term treatment.

While making a diagnosis, it is necessary to correctly determine the damage and analyze the external factors that can cause it. The close linking of effects to causes will significantly reduce the scope of the search area.

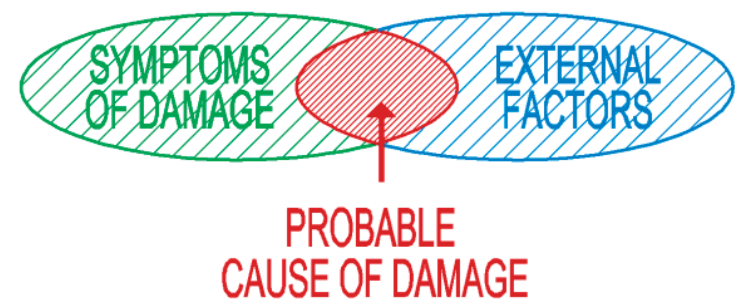

Fig. 2. Scheme of determining the cause of the damage

After finding the common part of causes and effects, a preliminary diagnosis should be made, which should be confirmed by research or structural analysis. Only after confirming the initial diagnosis there is possibility of proper selection of repairs.

\subsection{Causes of damage to the masonry wall's structure}

Defects arising in the construction of the masonry walls are usually determined by the condition of the wall itself. It may be possible to exhaust the load bearing capacity over time due to changes in physical parameters of materials. These changes are most often caused by the degradation of their structure. The structural degradation occurs due to external factors and related processes. The main reasons for the destruction of structural elements are:

- freezing and thawing of water bounded in the structure of the wall elements,

- crystallising salts, which are present in the structure of materials,

- erosion of masonry materials due to the effects of wind,

- development of biological corrosion due to the excessive moisture.

Strong degradation of the masonry material is usually the first stage of the structure's damage and significantly contributes to the start of the remaining stages (the appearance of cracks and scratches). As a rule, there are more factors in the destruction process. Firstly, slow and gradual destruction begins, and then as a result of the weakening of the structural elements, their susceptibility to deformation increases. 


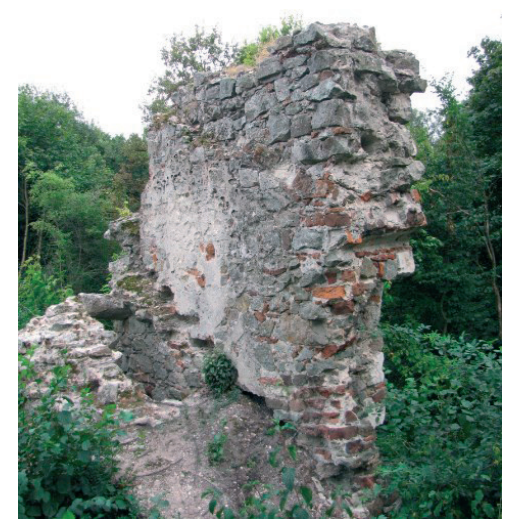

Photo 1. Degradation of the wall due to the environmental factors /Międzygórz castle/

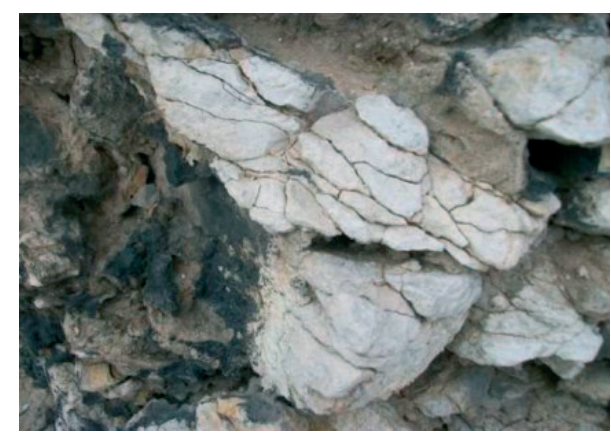

Photo 2. Cracking of a masonry material / castle in Rabsztyn/

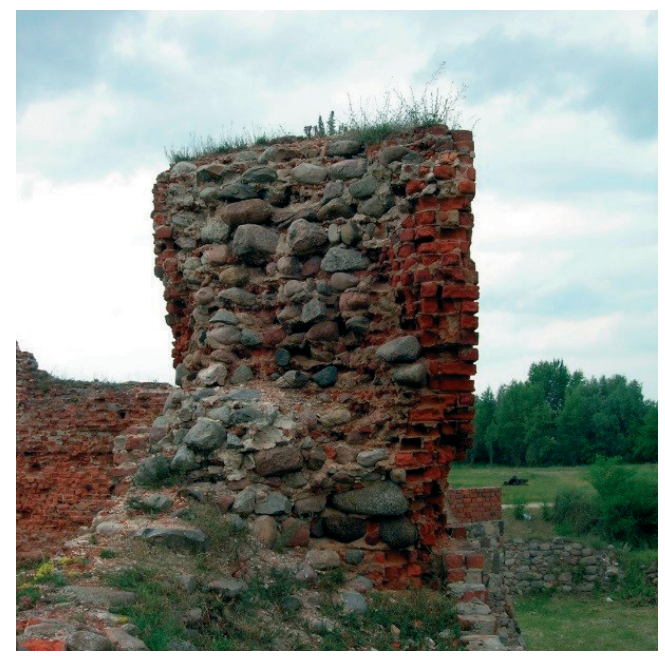

Photo 3. Damages of the "opus emplectum" wall (photographer - Marek Krysiński) /Międzygórz castle/

In the case of buildings erected today in accordance with [2] to structural damage of the masonry walls most often occurs as a result of the foundations settlement (up to approx. $60-70 \%$ of all cases). Definitely less, because only $15-20 \%$ of damage is caused by exceeding the load bearing capacity of the walls, and it takes place mainly in window pillars or arcade pillars. Other damages are the result of thermal loads, dynamic loads, and exceptional loads. In the author's opinion, these statistics can also be applied to the permanent ruin objects, bearing in mind that to the appearance of scratches and cracks usually occurs after significant degradation of the wall itself.

\subsection{Characteristics of the masonry walls' defects}

Usually, on the basis of damage (mainly cracks and scratches) it is possible to determine the reasons for their formation. To clarify these reasons, an analysis should be made and the morphology of their creation should be investigated. The situation can be much more complicated if the influence has more than one factor. The typical defects of the structure and their division with regard to the factors that cause them are presented below. 
- Uneven settlement of soil under foundations - by far the most common cause of damage to the masonry structures. Depending on the way the foundation settles, the cracks may have a different course and character. Defects in structures always arise in the most strenuous places - those in which the stresses in the material are the greatest. These stresses will have a diversified distribution, which depend not only on the part that deforms ("settles") but also on the proportions of the structure's elements (width, height, and thickness), proportion, type of the wall elements, number of holes, previous damage, and even earlier repairs. Exemplary, ideological stress distributions are shown in Fig. 3 as pressure lines in the masonry wall. In addition, places were also marked where scratches and cracks appeared.

a)

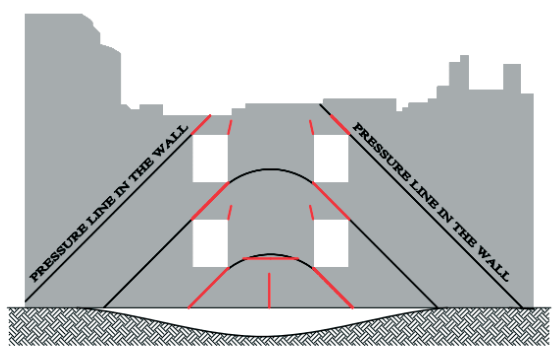

b)

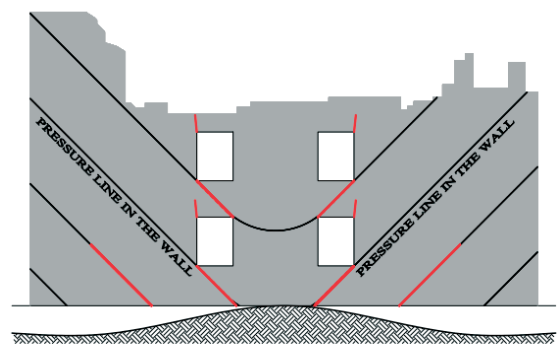

c)

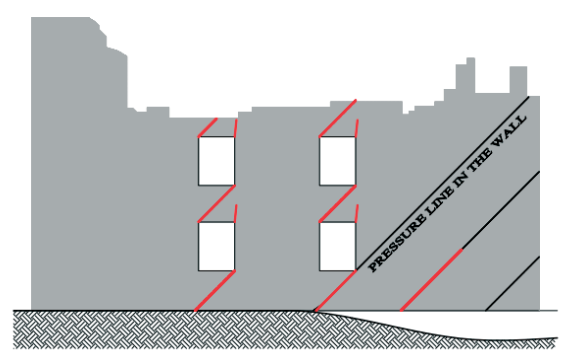

Fig. 3. The ideological course of the pressure line and damage in the wall due to: a) settlement of the central part of the wall, b) settlement of both wall corners, c) settlement one of the corners [3]

After making a preliminary diagnosis of the wall cracks caused by the settlement, it should be confirmed by conducting appropriate tests by an authorized geotechnician. First of all, the soil boreholes should be made in the places where the damage appeared. Next the comparison with the previous results or with the parameters of the land, on which no damage occurred should be performed. The settlement phenomenon can also take place as a result of the rise of the groundwater level, which should also be checked.

Diagnosing whether consolidation has taken place in the soil can be a complex, timeconsuming, and expensive task. If it is not possible to unambiguously confirm the change of soil and water parameters after performing basic tests, it is necessary to carry out tests in the extended scope with the use of specialized equipment for the soil diagnostics. Then all soil parameters should be determined in the laboratory. It is also recommended to prepare a detailed subsoil documentation.

In addition, in the case of this type of damage, permanent monitoring of the structure is recommended in order to determine whether the processes that occurred were only the one-time rockbursts or if the structure is constantly deforming. The construction monitoring can be performed using geodetic methods or commonly available feeler gauges. 


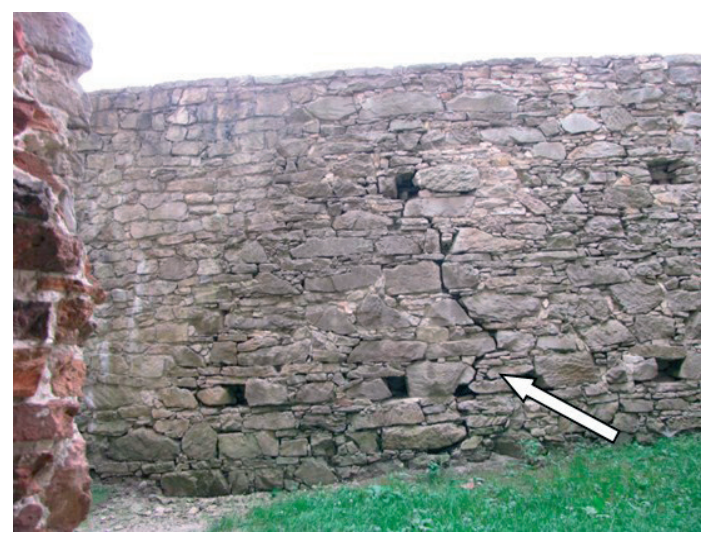

Photo 4. Damage caused by uneven settlement /Krzyżtopór castle in Ujazd/

- Excessive vertical loads (parallel to the wall's surface) - this is a much rarer situation in the case of the masonry facilities, and even rarer in the case of the permanent ruin masonry buildings. Due to the very large thickness of the masonry walls in the objects of the historic ruins, the walls have high strength parameters.

Exceptional situations may be situations in which the following occurred:

o damage to a fragment of the wall (change of the static scheme or its slenderness),

$\circ$ increasing the loads transferred to the wall caused by changes in the operation of the facility,

o significant corrosion and degradation of elements of the masonry structure that negatively affect its physical properties.

The phases of destruction of the brick wall are shown below in Fig. 4 . In the case of constructions made in another technology, the destruction phases will be similar.

a)

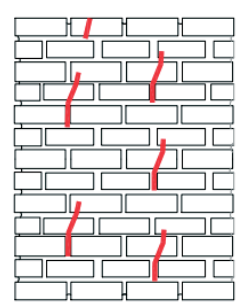

b)

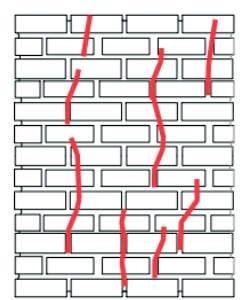

c)

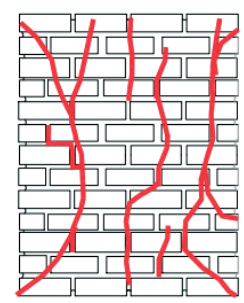

Fig. 4. Phases of the wall destruction: a) first phase - appearance of small cracks, b) second phase widening of cracks, merging of cracks and appearance of the first scratches, c) third phase - connection of scratches and cracks - the construction failure [4]

The first phase of destruction of a masonry structure does not threaten the safety of its use, however it may herald further damage to the element. It is therefore a signal of the possibility of danger when the loads will be increasing or steps are not be taken to repair or strengthen the structure. After observing even small scratches and cracks of a character as in Fig. 4, a permanent monitoring of the structure is recommended. Using the simplest feeler gauges, gypsum seals or glass plates, information will be received whether it is subjected to further damage, and whether it is possible to move to the next phase of the wall destruction. The next phase may already threaten the safety of the facility's use. In the event of the second or third phase, immediate steps should be taken to secure or reinforce the structure. 


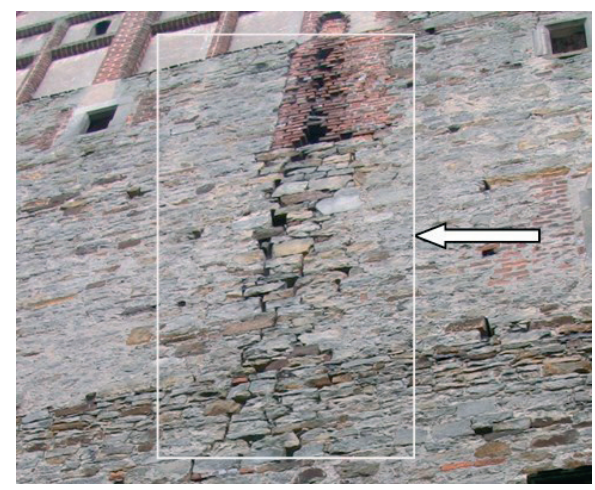

Photo 5. Damage to the masonry structure /castle in Drzewica/

- Excessive horizontal loads (perpendicular to the wall's surface) - damage due to excessive horizontal loads occurs mainly due to the effects of wind or inadequate use of the object. As unsuitable use, it is understood that the walls are loaded by covering with soil or disturbing the balance of forces by, e.g., digging out an underground part of the wall on one side only. In the case of objects in ruin, walls with a significant slenderness (e.g., slender attic) are exposed to external loads.

a)

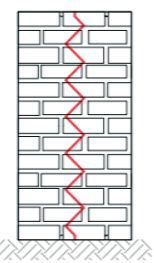

b)

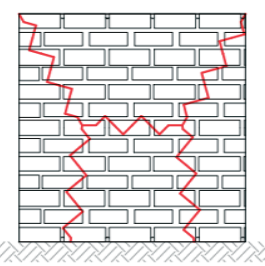

c)

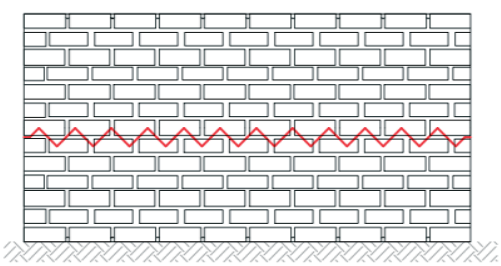

Fig. 5. Damage to the brick elements caused by excessive horizontal force (perpendicular to the element's plane) depending on the proportion of the element: a) slender elements, b) similar height and length, c) elements with a significant length in relation to the height [2]

In the case of appearance of similar cracks, as in previous cases, the permanent monitoring of the structure should be carried out, and in the case of free-standing elements, also geodetic surveys of the wall's verticality should be performed.

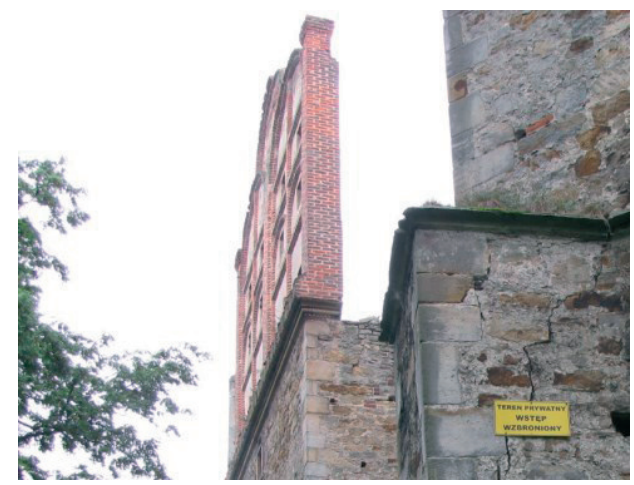

Photo 6. Examples of cracks in a slender attic wall /castle in Drzewica/ 
- Cracks in the corners of the holes - due to the nature of the stress propagation in the elements, the stress concentration always occurs in the holes' corners (stresses have the highest values there). Scratches or cracks originating in the convex corner do not necessarily mean the damage to the wall structure in the immediate vicinity of the visible defect. Appearing cracks and scratches, however, are a clear signal that the structure could have unplanned deformations and subsequent damage may appear elsewhere and could be more dangerous in its effects. As a rule, single cracks appearing in the corners of the window openings with not considerable length and width are not direct threat to the structure's elements.

The only exception is the situation where the window head itself has been damaged. The window head damage may occur due to the exhaustion of its load bearing capacity caused by an excessive load or corrosion, and destruction of the materials from which the window head is made. Depending on the window head's type, the cracks may have a very different course. In the case of arched window heads, the damage is usually perpendicular to the arch, while in the case of flat window heads - directed towards each other (Fig. 6).

a)

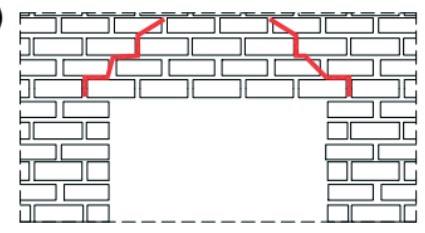

b)

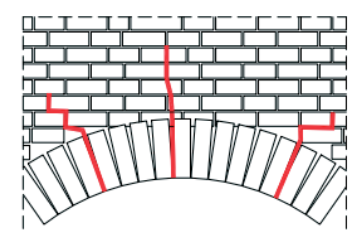

Fig. 6. Damage to the window head's elements: a) flat window head, b) arched window head

These defects should be constantly monitored, in the same way as in other cases.

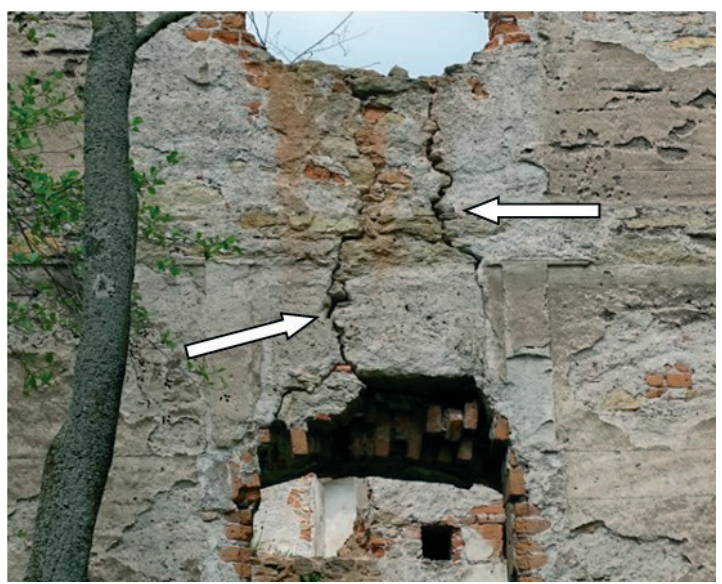

Photo 7. Example of the window head's damage /Panków castle/

\section{Repairs of the masonry structures}

There are a lot of repairs methods to damaged masonry structures. It should be remembered about the specificity of the historic buildings, and in particular the permanent ruins. The ruin buildings usually have little materials, so in their case, further depletion of a historical material could have a negative impact on the reception of the monument itself. Below, has 
been presented and briefly described the repair works of the masonry walls, which were assembled on the basis of completed, analyzed construction and executive projects, interviews with users and managers, and a local vision on nearly 50 permanent ruin buildings in Poland and abroad. The repair method depends mainly on the scale of the element's damage.

The most commonly actions performed during reinforcing masonry structures are included:

- Rebuilding of the structure's fragments - very often used and in some cases the only possible method. The fragments of the wall should be rebuilded in the case of highly damaged walls, severely degraded or so damaged that all other methods are not justified technologically and economically. With the help of rebuilding it is possible to almost completely get rid of the damaged material, and replace it with a new material - completely healthy. Unfortunately, this treatment is associated with the depletion of the historical material in the element itself. There are situations in which it is possible to rebuild or supplement a damaged part of the wall with historical material originating from another part of the building, however, due to the high value of such material and often insufficient technical condition, these are rare situations.

Before proceeding with the rebuilding, an appropriate technical documentation should be made with the determination of the technology of conducting the works. The procedure itself may seem relatively simple, but its unskillful performance may result in negative consequences in the further operation of the facility. Materials used for the rebuilding process should be chosen by a suitably qualified person. The selection of not suitable materials (e.g., a cement mortar or too strong masonry material) can lead to acceleration of the masonry degradation process or even its complete destruction.

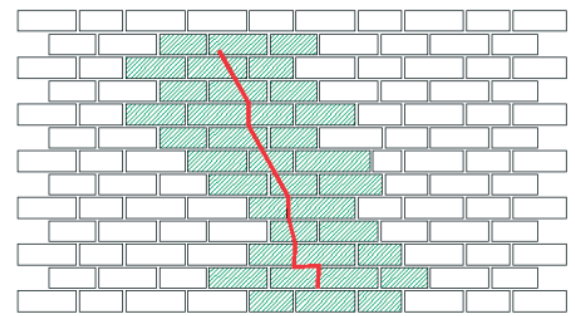

Fig. 7. Scheme of the wall rebuilding

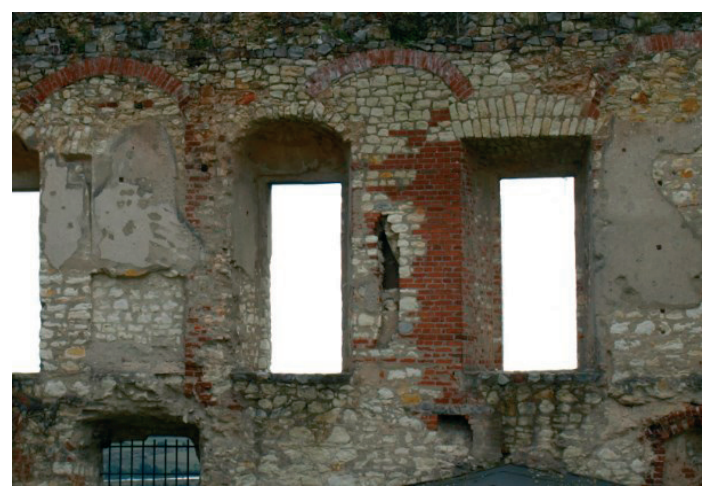

Photo 8. Fragments of the wall rebuilded /castle in Janowiec/

In the degradated element, not only the damaged parts should be rebuilded but also elements in the immediate vicinity. This will ensure better cooperation and binding of the wall's construction.

- stitching the walls with steel rods - one of the most frequently used methods of the masonry repairs. Stitching the walls finds its application in cases when the damage is not so large that it would be not reasonable to completely rebuild the wall's fragment. There are currently many system solutions for this type of repairs. All these solutions are, in principle, very similar or even identical. They consist in the introduction of a steel element, which is often a stainless steel rod in the joint or in a pointed incision (in the case of walls with an irregular joint, it is allowed to cut the structure) that is perpendicular to the crack's 
direction. The reinforcement introduced takes over the tensile forces that previously contributed to the damage of the structural element. It should be remembered that if the cause of cracking will not be removed and the local wall reinforcement will be made, a situation may occur in which the damage may appear on another part of the wall. The local repair strengthens a fragment of the wall and the stresses occurring in it can damage other places with poorer physical parameters.

The wall stitching is carried out by making a cut or crushing the joint to a depth of usually about $3-4 \mathrm{~cm}$. The joint should be properly cleaned with compressed air, and then moistened so that it does not absorb water from the repair materials, which is necessary for the hydration processes. After cleaning, a primer preparation (about 1-2 cm) should be introduced into the joint. Then, in the joint and the unbinded primer preparation a system steel rod is introduced. Information on the type, diameter of the rod, vertical spacing, and a furrow's width are dependent on the nature of the damage. They should be included in the design documentation.

An exemplary scheme for repairing a cracked wall using system bars is shown in Fig. 8.
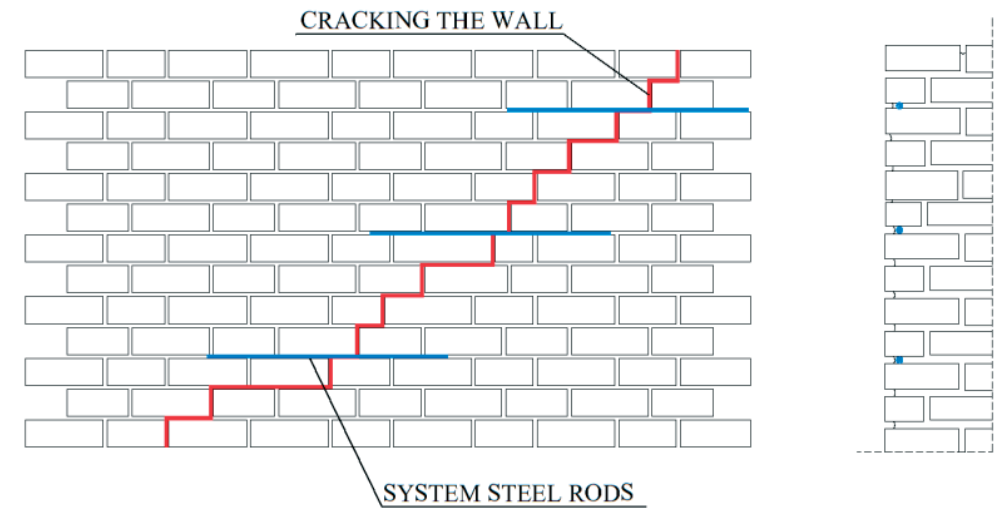

Fig. 8. Scheme of the wall's structure repair by using system steel rods

- repair by the FRP tapes - the method, which is very similar to the method of stitching walls with steel rods. The principle of repair is very similar. It involves removing a part of the wall's face or making a furrow in the wall's fragment. Then the FRP system tapes (carbon fiber tapes) are assembled using a mortar or system glue in a furrow followed by restoring the wall's face or making grouting. The widths and lengths of tapes are varied, which depend on the damage. As in the case of stitching walls with rods, these parameters should be included in the technological project. However, strict adherence to the technological regimes is necessary. This applies to the preparation of the substrate, which must be sufficiently strong and free from major unevenness so as to preserve the adhesion of the introduced element.

- nailing - the method is mainly used to stabilize walls of large thickness (most often erected in the "opus emplectum" technology). Strength parameters of the masonry structure, after its delamination, are significantly reduced. Deterioration of these parameters may result in further damage or even failure of the entire structure. To prevent the walls' delamination, various types of anchors are used. As a rule, these are steel anchors, sometimes with retaining elements (blocks, sheets, special shapes). The anchors are inserted into the pre-drilled holes filled with injections causing adhesion to the material. Depending on the wall's type and the technology chosen, mainly resin or mineral injections (microcementes, special cement pastes) are used. 


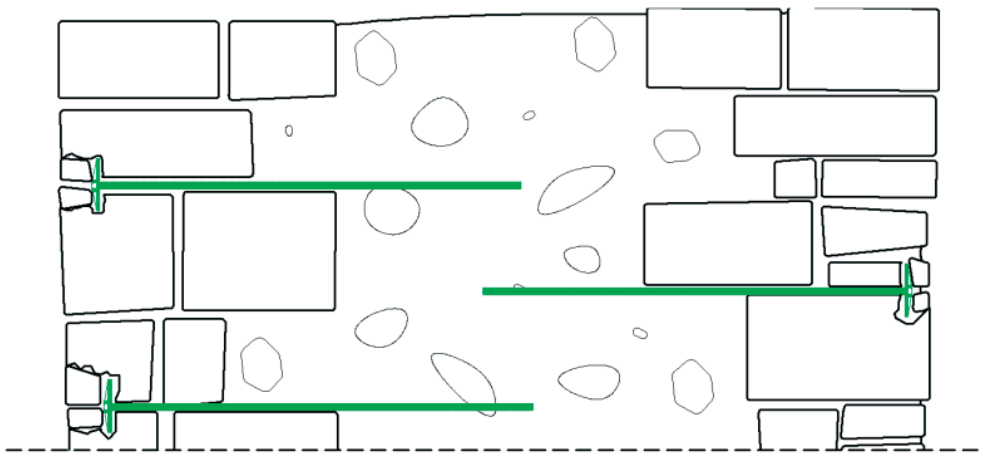

Fig. 9. Scheme of nailing with the supplementation of the wall's face of the „opus emplectum” type

- nailing with meshing - a method similar to the traditional nailing, with the difference that a steel mesh is also installed for reinforcement or protection purposes. Steel mesh can be made and fastened mainly in two ways. The first consists in the appropriate furrows making, and then the embedding of the pre-prepared mesh and restoring the joint (embedding technology is identical as in the case of the stitching method). The second method applies only to the protection of the wall's face. Between the anchors and the face of the wall, a steel safety mesh is mounted (photo 6).

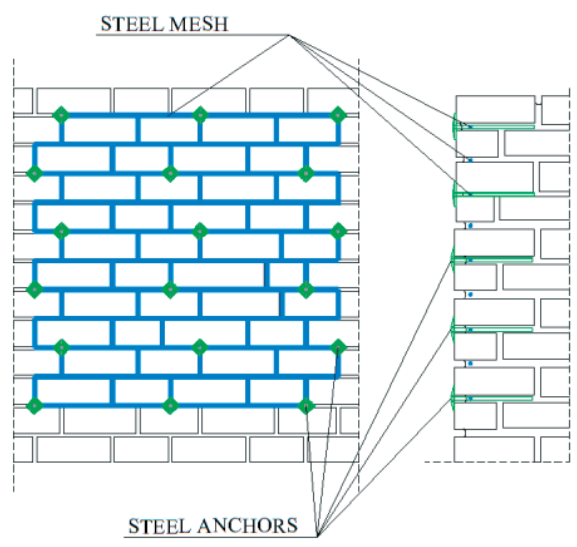

Fig. 10. Scheme of the wall's repair using an anchored steel mesh

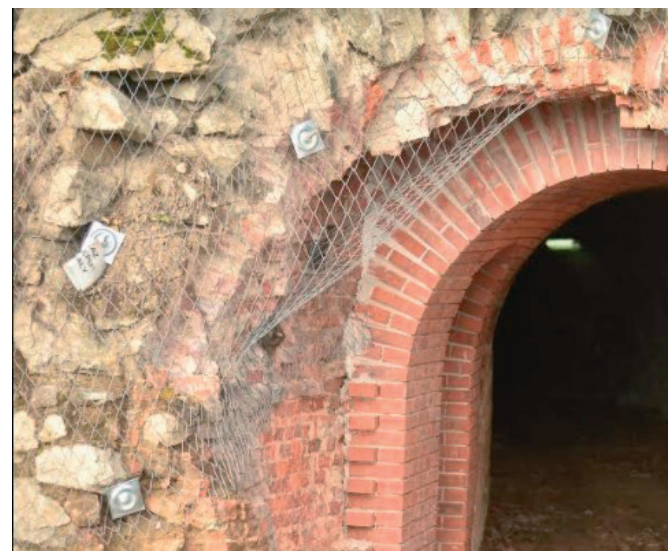

Photo 9. Protection of the damaged wall's face with a steel mesh mounted by the anchors (photographer - Grzegorz Basiński)

- injection into cracks and scratches - consists in inserting the injection solution into the very narrow slits. It is important that the modulus of elasticity of the preparation should be significantly greater than the material being repaired that no secondary dilatationlike cracks occurred. The strength of the material should not be less than the strength of the masonry material - the combination of the injection with the wall elements should monolithise the structure. Depending on the width of cracks, stabilization of the structure, and its moisture level, various types of injection materials are used:

- In the case of cracks with a width of less than $0.3 \mathrm{~mm}$, only resin injections may be used; in the case of the cracks' widths of $0.3-0.5 \mathrm{~mm}$, it is also allowed to use the microcements and cement pastes. In the case of cracks with significant widths 
(larger than $5 \mathrm{~mm}$ ), in addition to injections, it is also recommended to perform wall stitching with the steel system rods.

- In the case of unstable elements (continuously deforming) it is acceptable to use only flexible resins.

- In the case of dry cracks and the application of injections made with cement pastes or the microcements, the joint must be moistened in advance.

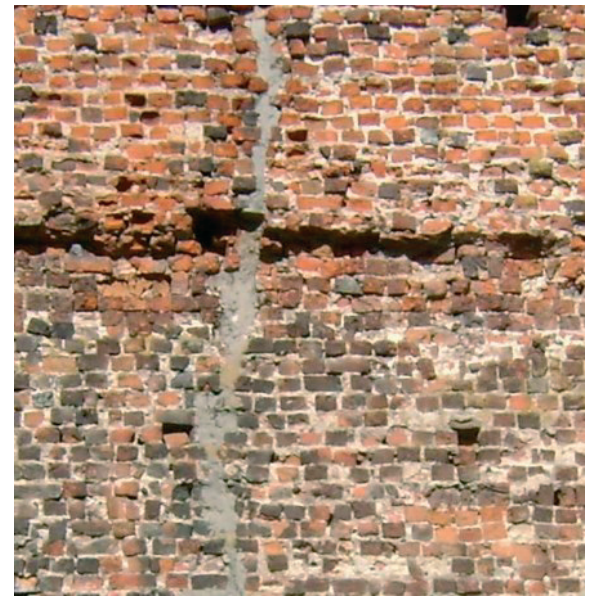

Photo 10. Injection into a crack with a cement mortar (photographer - Sylwester Zieńczuk) /castle in Liwa/

\section{Summary}

The walls of the permanent ruin buildings are very specific. The building solutions used in them are not typical today. It forces both designers and contractors to properly prepare substantive and technical content before starting a repair. In addition to the complexity of repair procedures, it is also important to respect the historical value and perform treatments only in accordance with the conservation doctrine or issued guidelines.

The analysis of the causes of damage and the ways of their repairs showed above all that this is not a marginal problem, but the issue very often is taken into account in technical studies regarding the permanent ruin. Due to the specificity of the buildings and the application of formerly common and diverse solutions to their construction, each case and object should be treated individually. Based on local visions, interviews with users, and analyzes of the documentation collected, it was founded that it was not possible to create a repair algorithm that would check each time.

\section{References}

1. Karczmarczyk S. Wzmacnianie i naprawy fundamentów murowych i kamiennych. Naprawy i wzmocnienia konstrukcji budowlanych: budownictwo ogólne: XXX Jubileuszowe Ogólnopolskie Warsztaty Pracy Projektanta Konstrukcji, Szczyrk, 25-28 marca 2015 roku. T.2, Wykłady. - Bielsko-Biała: Polski Związek Inżynierów i Techników Budownictwa. Oddział w Bielsku-Białej, 2015. - s. 213-231: fot., rys., schem. - Bibliogr. 14 poz. - ISBN 978-83932934-4-5 (T. 2). - ISBN 978-83-932934-6-9 (całość).

2. Drobiec Ł. Przyczyny uszkodzeń murów. XXII Ogólnopolska Konferencja „Warsztaty Pracy Projektanta Konstrukcji”, Szczyrk 2007. 
3. Stawiski B. Konstrukcje murowe. Naprawy $i$ wzmocnienia. Oficyna Wydawnicza POLCEN, Warszawa 2014, ISBN 978-83-89234-64-3.

4. Żenczykowski W. Budownictwo ogólne. t. 2/1, t. 2/2, Arkady, Warszawa 1981.

5. Binda L., Modena C., Baronio G. Strengthening of masonries by injection technique. (3rd Edition), Proc. of 6 NAMC, Vol. I (1993), pp. 1-14.

6. Binda L., Modena C., Baronio G., Abbaneo S., Repair and investigation techniques for stone masonry walls. Construction and Building Materials 11(3) (1997) 133-142.

7. Binda L., Modena C., Baronio G., Gelmi A. Experimental qualification of injection admixtures used for repair and strengthening of stone masonry walls. (3rd Edition), $10^{\text {th }}$ Int. Brick/Block Masonry Conf., Calgary, Vol.2 (1994), pp. 539-548.

8. Hendry A.W. Structural Masonry. MacMillan Education Ltd, 1990.

9. Santa-Maria H., Alcaino P. Repair of in-plane shear damaged masonry walls with external FRP. Construction and Building Materials 25(3) (2011) 1172-1180.

10. Małyszko L., Orłowicz R. Konstrukcje murowe. Zarysowania i naprawy. Wydawnictwo Uniwersytetu Warmińsko-Mazurskiego, Olsztyn, 2000.

11. Masłowski E., Spiżewska D. Wzmacnianie konstrukcji budowlanych. wyd. 3, Arkady, Warszawa, 2000.

12. Rudziński L. Konstrukcje murowe - remonty $i$ wzmocnienia. Wydawnictwo Politechniki Świętokrzyskiej, Kielce, 2010.

13. Sousa H., Thomaz E., Humberto R., Morton J., Silva J.M., Corrêa M., Pfeffermann O., Lourenço Paulo B., Vicente Romeu S., Sousa R. Defects in Masonry Walls. Guidance on Cracking: Identification, Prevention and Repair. International Council for Research and Innovation in Building and Construction CIB W023 - Wall Structures.

14. Triantafillou T.C. Strengthening of masonry structures using epoxy-bonded FRP J Compos Constr ASCE 2(2) (1998) 96-104. 